\title{
Sustainable Systems of Agri-tourism in a Cherry-growing Area: A Case Study of the Miizumi Area, Sagae City, Yamagata Prefecture
}

\author{
HAYASHI Takuya \\ Faculty of Regional Studies, Gifu University; Gifu 501-1193, Japan. \\ E-mail: tak3ai@gifu-u.ac.jp
}

Received September 4, 2009; Accepted December 8, 2009

\begin{abstract}
This study attempted to clarify sustainable systems of agri-tourism in a cherry-growing area. In Sagae city, cherry picking was started in the latter half of the 1960s when some farmers received tourists through a travel company of Sendai city. Then, some farmers organized group for cherry picking and stepped up efforts to engage in agri-tourism. In the 1980s, a window of agri-tourism was included in the agricultural cooperative to correspond to tourism demand and to unify service and pricing of many pick-your-own farms. At cherry harvest time, the agricultural cooperative arranged for media to focus on the cherry of Sagae city and aimed at the new business development of market and the improvement of publicity. When cherry for direct selling was not enough, farms engaged in agri-tourism were supplied cherries through cherry shipment group of the agricultural cooperative. Thus, it was important that the farms which were engaged in agri-tourism maintained good relations with the other farms and with the agricultural cooperative. This research analyzed agri-tourism of the Miizumi area as a study of the most prosperous case. In the Miizumi area, there were a lot of opportunities and activities to improve cultivation technique of all farmers regardless of the difference of the sales system. This brought a tolerant atmosphere to enable sales through various distribution channels among farmers. In addition, high quality cherries that were supplied through various distribution channels improved the publicity as "cherry of Miizumi or Sagae" and, as a result, it had many effects on regional agriculture development. This shows one possibility for agri-tourism development in a large growing area.
\end{abstract}

Key words agri-tourism, cherry-growing area, sustainable system, succession and sharing of cultivation technique, Sagae City, Yamagata Prefecture

\section{Introduction}

\section{Research purpose}

Rural areas have been traditionally characterized by low population density, extensive land use, and primary industry (Clout 1972). However, since the 1970s, it has become difficult to prove that the primary sectors such as agriculture and forestry constitute the main rural economic activities in many advanced countries (Takahashi 1998, 1999; Tachikawa 2005). As a result, many researchers studying rural areas began to describe rural areas as having multiple functions, such as leisure, recreation, education, environmental purification, water recharge, and preservation of ecosystems, in addition to carrying out food production (Ilbery and Bowler 1998). In Japan, the Basic Law on Food, Agriculture, and Rural Areas enacted in 1999 emphasizes rural non-agricultural functions such as land conservation, water recharge, conservation of the natural environment, formation of good scenery, and the preservation of traditional culture.
The law specifies that these functions need to be fully and appropriately sustained in the future, in order to stabilize people's lives and the national economy. In particular, rural areas have the potential for further development by becoming destinations for tourism and recreational activities (Hall and Page 2006). In Europe and North America, various recreational and tourism activities have been developed in rural areas. ${ }^{1}$

However, tourism activities have already been available in rural areas. Pick-your-own farms were the pioneering example of introducing city residents to the tourism element of farm operation (Bowler 1981, 1982; Bryant and Johnston 1992). In Japan, pick-your-own farms have spread in the suburbs of large metropolitan areas and in the vicinities of tourist areas. ${ }^{2}$ It was a high economic growth period. At this time, people's incomes increased and their leisure time expanded. Many people could afford to own cars, and tourism demands increased by leaps and bounds. Pick-your-own farm management provides sufficient income to farm households in addition 
to sustaining agricultural activities and maintaining rural landscapes (Nakajima 1996). In Japan, because the market size of day-trippers is large (Ohe 2003), pick-your-own farms can effectively respond to their needs.

A variety of pick-your-own farms exist in Japan. For example, stone-wall strawberry picking, developed in the 1970s near tourist sites such as the Kunosan Toshogu Shrine and the Miho Pine Forests in Shizuoka Prefecture (Iguchi et al. 2008). Apple-picking in the Nagano basin was started by neighboring farmers in order to sell apples directly to the visiting worshipers at Zenko-ji Temple (Matsuda 1973). In the case of Tamagawa pears, a private railway company advised local farmers to start pick-yourown farm operations in order to increase the number of railway passengers (Yamamura and Ura 1982). Other illustrative examples include the development of the Ashigakubo Fruits Park by the Seibu Railway Company (Tanno 1974), sweet-potato harvesting in Hachioji City by the Keio Electric Railway Company (Hirayama 1972), and strawberry-picking in Kita-ku of Kobe City by the Kobe Electric Railway Company (Tanabe 1985). Most of previous studies on pick-your-own farms tended to analyze the characteristic of farm management and review development processes and regional conditions.

From the 1980s to the 1990s, an increasing number of studies analyzed pick-your-own farms as the means of rural development or regional revitalization. For example, cooperation with surrounding tourist sites and importance of green tourism were pointed out (Tanabe 1985, 1988; Sukeshige 1990; Kawahara 1996; Kikuchi 1997; Suzuki 1999; Nakayama 1999, 2000). ${ }^{3}$ When there are many pick-your-own farms in the same area, cooperation among the various types of farms was absolutely necessary (Koike 2002). In the case of a groupbased pick-your-own operation, a close information exchange and familiar relationships among farmers were important for success (Hayashi et al. 2004). These studies focused rather on the possibility of organized farm operation than its characteristics. Such viewpoints are also found in agro-economic research. A successful pickyour-own farm operation depends upon the organization of management and year-round operations. Broader cooperation among municipalities is indispensable (Suda and Ishigaki 2001; Ueda et al. 2002). Furthermore, it is shown that pick-your-own farms have the added function of successfully advertising the direct sales of farm products and door-to-door delivery service to consumers, in addition to the advantageous sales of agricultural products (Saito et al. 1998; Tsuji and Mitsusada 2003). In recent years, pick-your-own farm operations have been considered a way to develop a local economy rather than a way to support farm income. At present many people, having no opportunity to experience farming and rural life, desire to spend time in the rural area. On the other hand, rural or agri-tourism is indispensable for sustaining farm management and developing regional agriculture. This activity meets the needs both of city dwellers and farmers. Since the 1990s, administrative supports have been provided, while rural tourism has received positive media coverage. These conditions enabled farmers to diversify their farm management (Tachikawa 2005; Akitsu 2007).

These studies showed that the adoption of tourism elements in rural areas strongly influenced local economy. In order to clarify the process and the regional conditions of rural tourism development by way of pick-your-own farm operation, it is necessary to analyze the roles of farmers' leader, farmers' groups and local administration. Analyses of these actors' mutual relationships are also necessary. However, it has not been fully considered what kind of human resources participated, and how they contributed to the tourism development of rural areas. Some studies in the present decade have begun to clarify the roles and characteristics of groups and individuals supporting tourism. Katori (2003) discussed the relationship between rural restructuring and green tourism, paying attention to the "depopulation of human resources." She highlighted the importance of the moving spirit who leads farmers. This shows that human resources, with their volition and energy, play an important role in rural restructuring. In the field of geography, many studies focused on the actors who lead rural development. Caballe (1999) and McGehee et al. (2007) pointed out the important role of female farmers (in reception or cooking) as the driving force of rural tourism. Ohe (2005) suggested that the practical use of farmers retired from non-farming job with rich social experiences is important for increasing the function of recreation and education in rural areas. Fujime and Yang (2004) examined the actual condition of the new entrant from other fields. Moreover, Gilg and Battershill (1999), considering those farmers who positively promote agritourism as entrepreneurs, ${ }^{4}$ pointed out that the farmer with an advanced academic background and social experience is important for diversification. Although the importance of actors and their roles supporting tourism are emphasized, there are few studies that show clearly how these actors became the driving force of agri-tourism via their cooperation with various human resources. For example, Hayashi (2007) showed the importance of local 
leaders (farmers' leaders) tying farms and administration for development of agri-tourism. The continuation of such a study is required to develop an ideal method of agri-tourism suitable for individual regional conditions. Moreover, agri-tourism was often considered a disincentive in maintaining regional agriculture in major growing areas with an existing distribution system and that markets and consumers evaluate (Sukeshige 1990). This attitude comes from the commonly held opinion that the best market-business method is the securing of large-lot farm products. However, the high publicity and evaluation becomes the source of consumption and tourism demand, and the demand of direct selling and picking is very high. In major growing areas, farms engaged in agri-tourism need various considerations and adjustments to other farms and/or the agricultural cooperative. Thus, it is necessary to clarify the following problems: (1) how to engage in agri-tourism, (2) the relationship between farms engaged in agri-tourism and the other farms, and (3) point of view to agri-tourism of agricultural cooperatives and non-tourism farms. Furthermore, this is an indispensable research theme to push forward the introduction of tourism elements to the agricultural sector.

Therefore, in this paper, I will clarify sustainable systems of agri-tourism. The study area is Sagae City, Murayama Region of Yamagata Prefecture, which is the largest cherry-growing area in Japan, and has long promoted agri-tourism.

\section{Research methodology}

The roles of farmers who promote agriculture and economic activities have been examined in previous studies that considered farming techniques, management innovation, and the adoption of new variety. Hayashi (1994) clearly showed that the role of practical farmers who adopted new variety strongly influenced their followers. Nihei (1998) emphasized the important role of practical farmers and agriculture-related contractors when farmers adopt a new farm operation and farming techniques. In addition, Oizumi (1996) showed that "leading farmers" who wielded a positive influence over regional agriculture often attract many followers. Previous studies have not fully examined how leaders as actors informed other farmers of their management views and policies (Haseyama 1988; Miyatake 2007). This point is not only important in agricultural economics, but also in agricultural and rural geography, which considers the characteristics and development of agricultural regions. Tabayashi (1994) pointed out the necessity of examining such farmers' personal conditions in detail, along with regional conditions.

Thus, this study examines the activities of farmers and their organizations that promote agri-tourism, especially paying attention to farmers' leaders, followers, farmers' organizations and the agricultural cooperative, in order to show how these actors formed the environment for agritourism development.

The "pick-your-own farm" used in this study refers to a farm at which farmers provide tourists and owner system members with the opportunity to pick and buy farm products directly. This type of farming contributes to stabilizing farm management of farmers, while providing consumers with farm experiences and fresh, safe farm products at a lower price (Wampler and Motes 1984; Yamazaki 1997; Tsujihara 2007). "Agri-tourism" is a type of agricultural enterprise combining farming and tourism, which strategically attracts many tourists and leads to the sales of agricultural products. McGehee and Kim (2004) suggested that agri-tourism includes farm stays, bed-\&-breakfasts, pick-your-own farms, direct selling, agricultural events, farm tours for children, and hayrides. This study defines "agri-tourism" as diversified farm management including direct selling, door-to-door delivery, and the interaction with city dwellers based mainly on the pick-your-own farm operation. A similar term, "rural tourism," describes recreational activities that use mainly regional resources in a rural area (Lane 1994; Sharpley and Sharpley 1997). Rural tourism is a wider concept including agri-tourism, for farmers and tourists have individual contact and the rural resource is commodified (Wilson et al. 2001; Kikuchi 2008).

\section{Background of Agri-Tourism in Sagae City, Yamagata Prefecture}

\section{Outline of Sagae City, Yamagata Prefecture}

Sagae City, Yamagata Prefecture, is in the Murayama region and is close to Sendai City (Figure 1). According to the 2005 census, the population of Sagae City was 43,625 . Agricultural production in 2005 was 8.3 billion yen, of which fruit accounted for 50.5\% (4.2 billion yen). The acreage for cherries-the main fruit-exceeded $400 \mathrm{ha}$, which is the third largest in Japan, after Higashine City and Tendo City. Until the late 1980s, Sagae City had the largest cherry acreage for a municipality in Japan. Sagae City and Giresun City in the Republic of Turkey became sister cities, because cherries originated in this region. In 1992, a theme park named The Cherry Land opened and still plays an important role in promoting 


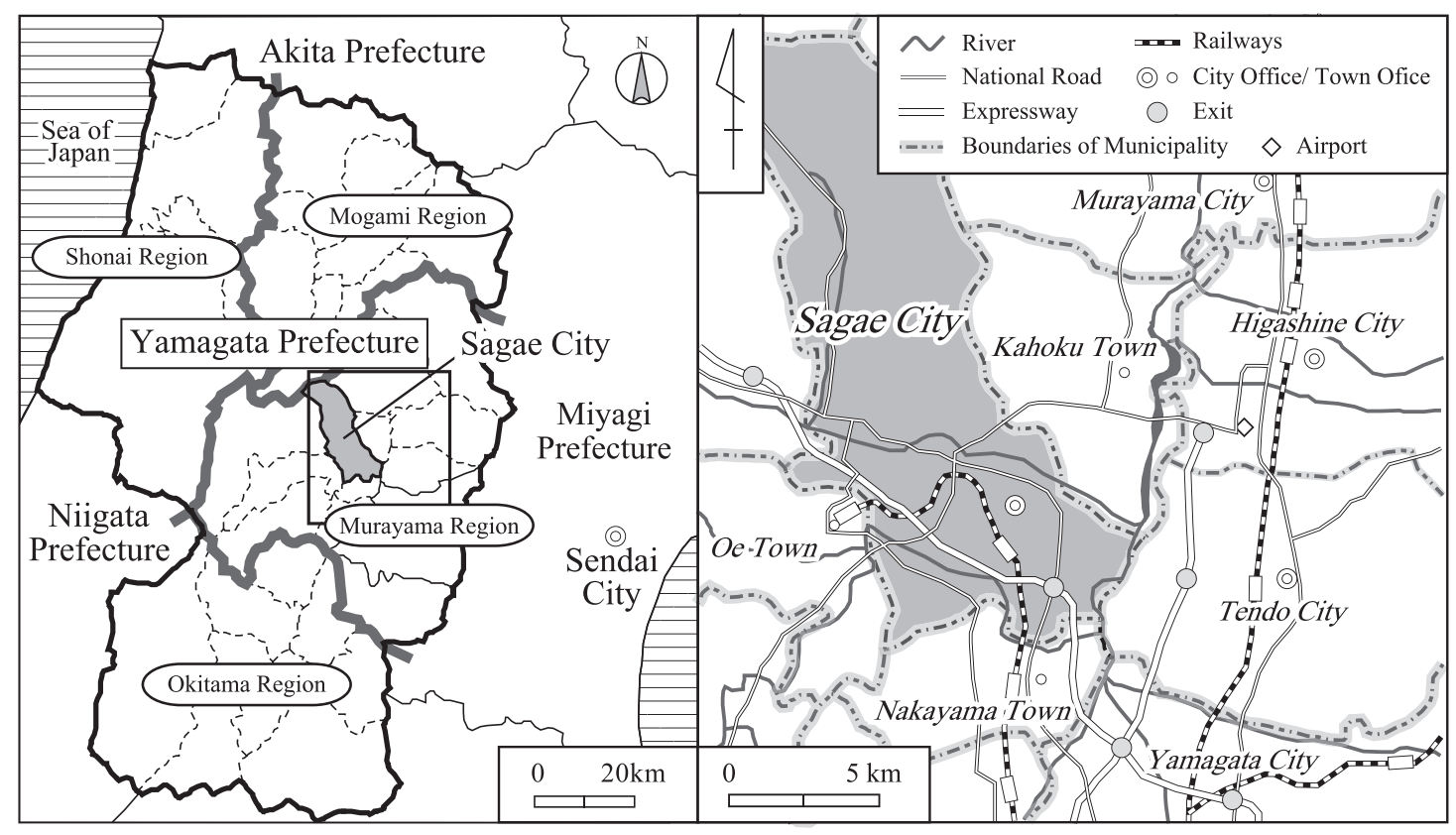

Figure 1. Location of Sagae City, Yamagata Prefecture (2007).

industry, culture, and tourism in the region. ${ }^{5}$ Since local government promoted town planning featuring cherries, Sagae City has become recognized as the most famous cherry-growing area in Japan, even though Higashine City and Tendo City both have more cherry acreage. Every third Sunday in June is The Cherry Day, and The Cherry Festival is held for a month from that day. During the festival, many events are held, including a Miss Cherry contest, a cherry marathon race, and a cherry-pit spitting contest.

\section{Changes in agriculture}

Fruit farming in Sagae City started in 1888, when an experimental station was established in old Shibahasi village (Shibahasi area of present-day Sagae City). This station promoted cherry cultivation by distributing cherry saplings to farmers in the neighboring districts. In the Showa Era, canning technology for cherries was established, which promoted cultivation, as cherries are easily spoiled by vibration and shock during transportation. In 1937, the Sagae agricultural cooperative (current Sagae-nishimurayama agricultural cooperative) started a cannery. Hikoyoshi Watanabe, who was a steward of the Sagae Cherry Cooperative, introduced Nitto food products at the same time. During World War II, orchards (including cherry trees) were cut down, and cherry canneries were closed. After 1955, some major fishery companies from other prefectures opened new factories in Sagae City. This led to the rapid re-development of cherry canneries, which started canning other fruits, such as peaches, in order to fully operate during all four seasons (Yamashita 1987; Nagaoka 1990). As a result, fruit farming matured, yet as Figure 2 shows, the agricultural crop in 1960 was only 1.7 billion yen, and the ratio of fruit was very low (18.3\%) compared with that of rice $(57.2 \%)$. In Japan, fruit farming enhanced its importance in regional agriculture after the implementation of rice production control in the 1970s. The ratio of orchards among all agricultural crops in 1975 rose to $39.4 \%$, or almost the same as that of rice $(40.8 \%)$. The fruit ratio gradually increased as fruit became a major item.

\section{Introduction of agri-tourism}

Tourism activity in the farm in Sagae City started in 1966, when the local government, Japan National Railways, and local transportation companies encouraged some farms to allow tourists to visit and pick cherries. In 1973, some farms offering cherry picking established cherry picking groups. At that time, land use changed from rice to fruit, and cherry acreage increased rapidly. Many farms built rain shelters with frames of pipe and roofs of plastic to protect the cherries and improve their quality. The expansion of cherry acreage and the improvement of the cherries' quality facilitated new construction of pick-your-own farms.

As the number of pick-your-own farms increased, some problems arose. For example, there was a disparity between cherry harvests and tourist demand, which resulted in entrance regulation of the tourists and disposal of the surplus cherries. Standardization of cherry prices and quality - and the improvement of the farmers' 
a) Number of farm households

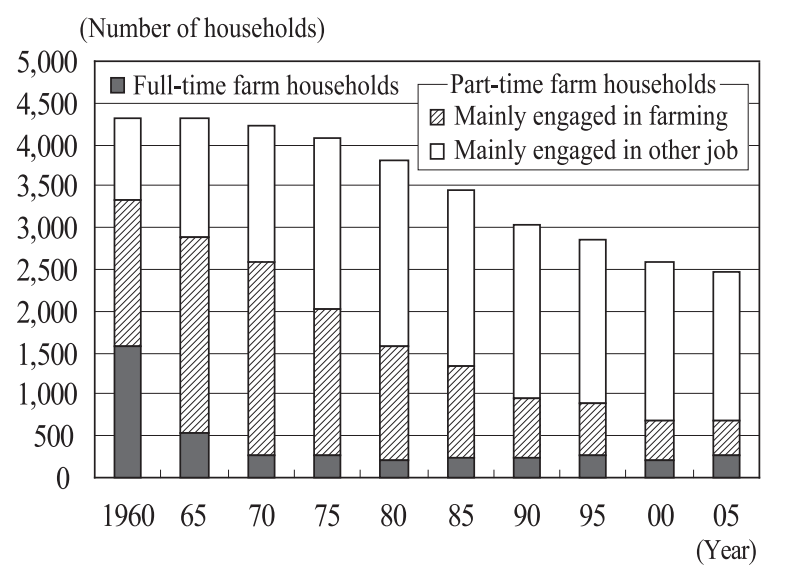

c) Rice acreage and yields

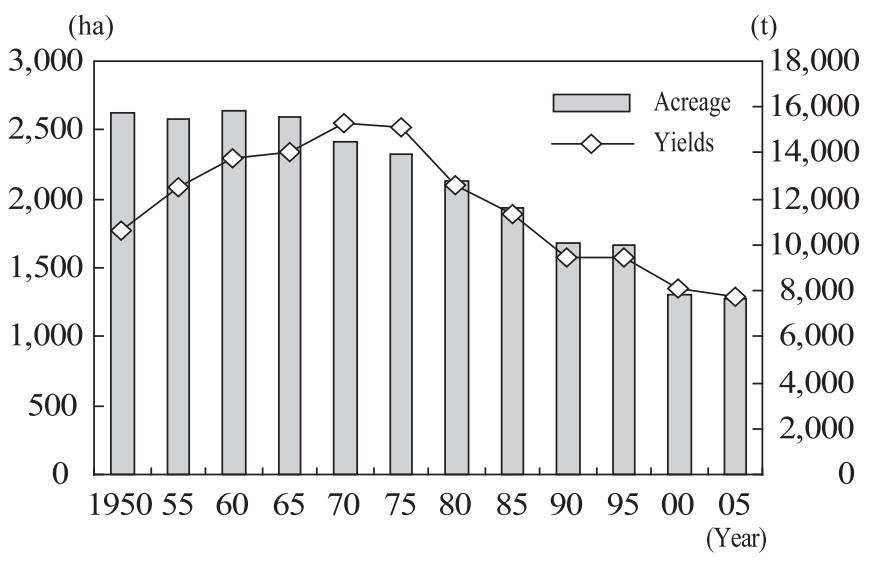

※ Figures after 1990 include the number of self-contained farm household.

b) Agriculture sales

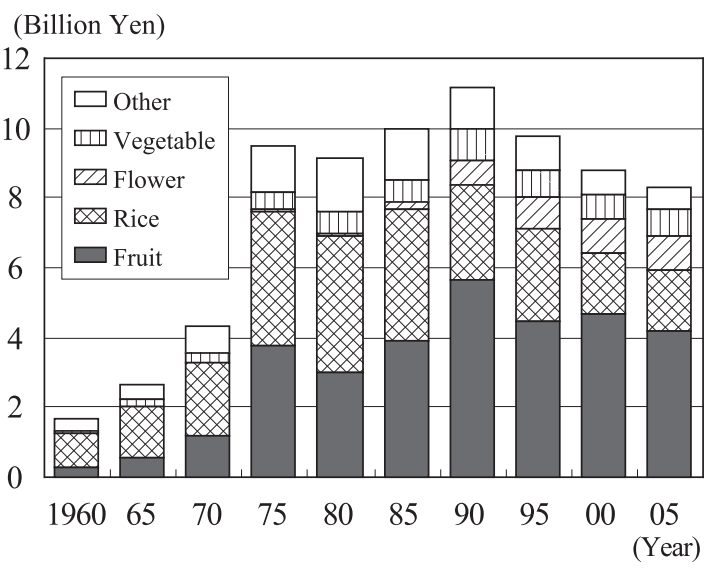

d) Acreage of cherry-growing area

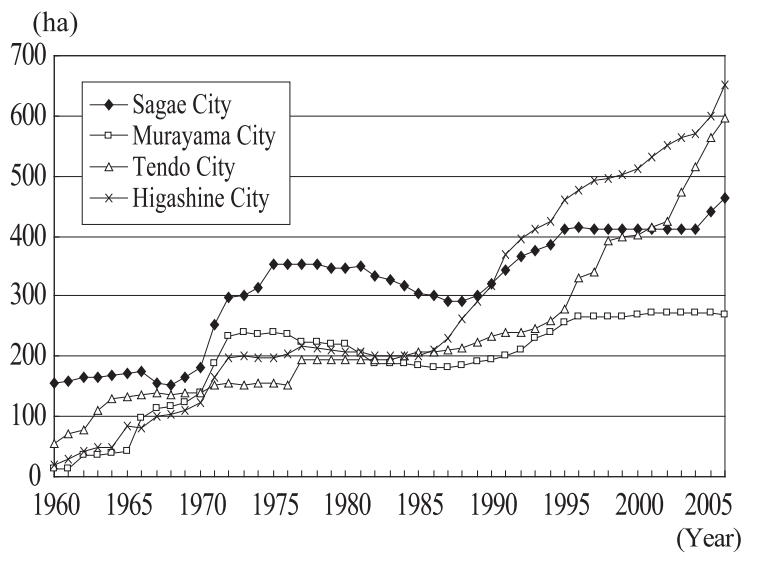

Figure 2. Changes in agriculture in Sagae City, Yamagata Prefecture.

Source: Census of Agriculture and Statistics of Yamagata Prefectural Government.

attitudes toward tourists-were needed. Therefore, Sagae City established a unified organization in 1979. After considerable discussions, the agricultural cooperative, Sagae City, and some of the farms established an agritourism association for all seasons using other fruits and flowers under the guidance of the agricultural cooperative. This effort involved substantial advertisements and operating activities and full instructions for farmers (Kudo and Hirai 1998). In this association, there are seven cherry-picking groups: Miizumi, Route No. 112, Sagae-ishimochi, Jionji, Nanbu, Nishine, and the Nitta Cherry Picking Group. In April 1994, Sagae City's agricultural cooperative merged with the four agricultural cooperatives in Nishimurayama County. This merger made it possible to accept many students who wanted some farm experiences in this county. As a result, the Sagae-nishimurayama agricultural cooperative, which manages some municipalities including Sagae City, could systematically organize many activities related to agri- tourism. For example, in this city, 99 farms operated pick-your-own farm, and 95 farms participated in this agricultural cooperative's agri-tourism association in 2007 (Figure 3). In contrast, although 40 farms operated pickyour-own farms in Tendo City, a neighbor of Sagae, only 21 farms participated in a pick-your-own farm conference in 2007. In Higashine City, only 28 of 40 farms operating pick-your-own farms participated in a pick-your-own farm conference organized by Higashine City Tourist Association in 2007. Thus, there are many farms that don't join the agri-tourism organization. In particular, each farm located along the main road tended to operate its pick-your-own operation independently. There was a lack of a systematic organization to promote regional agriculture.

\section{Mechanism of agri-tourism by Sagae- Nishimurayama Agricultural Cooperative}

In 2006, the amount of cherries produced by 


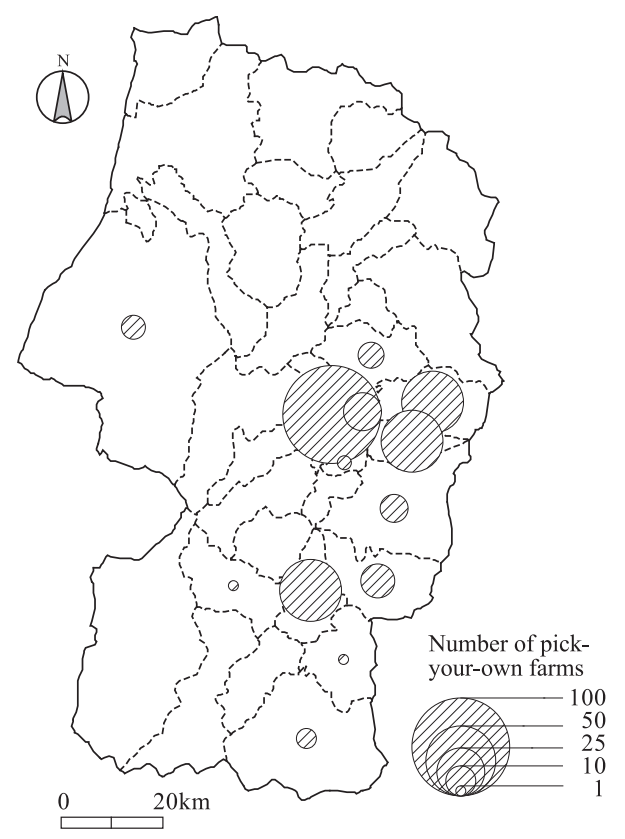

Figure 3. Pick-your-own cherry farms in Yamagata Prefecture (2007).

Source: Yamagata Prefectural Green Tourism Conference, Yamagata Prefectural Tourist Information Center, SagaeNishimurayama agricultural cooperative, Higashine City Tourist Association, Tendo City Office.

farm households in Sagae City through the Sagaenishimurayama agricultural cooperative reached 801 tons, which was only $40.7 \%$ of the city's total cherry shipments of 1,967 tons. Although we cannot say that all other cherries were sold without market distribution, the expansion of direct sales by the farms is not desirable by the agricultural cooperative, as it tries to maintain the sales advantages of the whole region. However, the agricultural cooperative actively supports agri-tourism, because direct selling through the agricultural cooperative raises the reputation of Sagae cherries and supports the region's reputation as a famous cherry-growing area.

The entrance fee at pick-your-own farms is 1,200 yen per hour at farms with rain shelters (including cherries cultivated in open fields), and 2,000 to 3,500 yen per hour at farms with greenhouses. In general, all tourists are required to make a reservation before they visit the pick-your-own farms, with some exceptions. The cherrypicking groups keep the standards unified and monitor the operations of the farms and the prices of cherries that are sold directly, so that there are not significant differences of agri-tourism among farmers in the same areas. Among the cherry-picking groups in each area, the Miizumi Cherry-Picking Group is the largest in terms of tourists and sales (Figure 4). The Nishine Cherry-Picking Group, including the Nitta Cherry-Picking Group, has the largest number of farms (24), followed by the Route

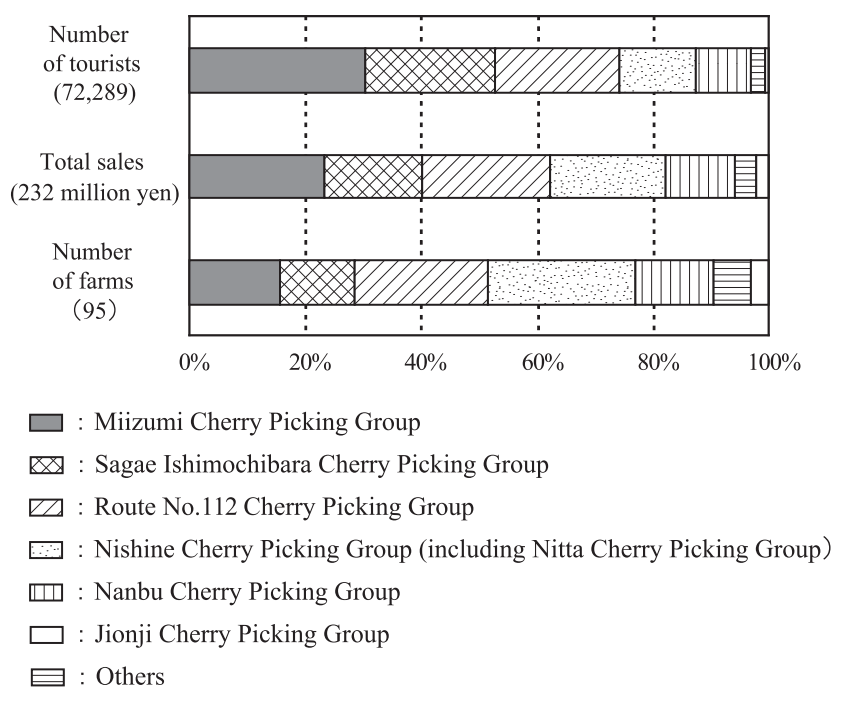

Figure 4. Cherry picking groups of SagaeNishimurayama Agricultural Cooperative (2007).

Source: Miizumi Cherry Picking Group.

No. 112 Cherry-Picking Group (22) and the Miizumi Cherry-Picking Group (15). Thus, the Miizumi CherryPicking Group gains the highest benefit per tourist and is managed the most efficiently. From this point forward, I will discuss agri-tourism in the Miizumi area.

\section{Classification of Farms Engaging in Agri-Tourism in the Miizumi Area}

\section{Development of cherry cultivation and introduction of agri-tourism}

Characteristics of the Miizumi area

The Miizumi area is located at the northeastern side of Sagae City, on the border between Sagae City and Kahoku Town and along the left side of Sagae River (Figure 5). There are six settlements in the Miizumi area: Dosho, Kamikawara, Nakagawara, Shimogawara, Kumogawara, and Nyugura (Miizumi Sonshi Hensan Iinkai 1971). Cherry cultivation started in the Meiji Era as a complementary product for the rice cultivation in this area. Until the beginning of the Showa Era, the economy of farm households consisted of growing rice, a cocoon crop, and the production of zori (Japanese sandals) during the off-seasons (Sagae Shishi Hensan Iinkai 2007). The expansion of cherry cultivation occurred in the 1930s, when some cherry canneries began operating. Later, rice production control started in 1970, and this enhanced cherry cultivation (Matsumura 1982). The sandy soil of the Miizumi area was well-suited to cultivating fruit. This is a result of sediment deposition to the bank of the Sagae river by the flooding of the river in the long history. 


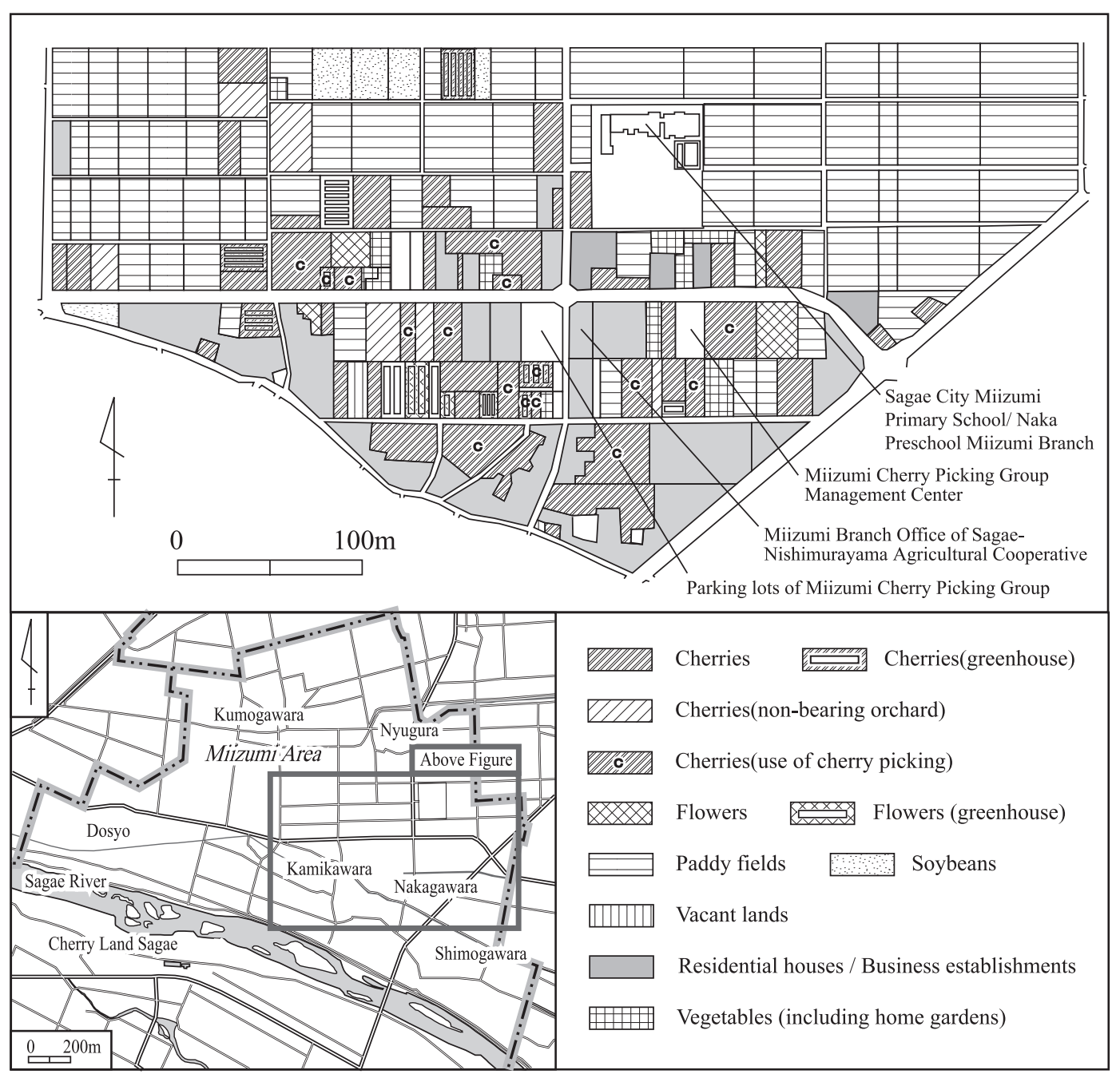

Figure 5. Land use in the Miizumi area of Sagae City in 2007.

Source: Land-use survey.

Between 1970 and 1980, the need for a new cherry distribution system emerged, because concern spread among consumers about the carcinogenicity of the artificial sugar cyclamate, which was used when canning cherries. As a result, farm households shifted into cultivating cherries as table fruits. A practical farmer in the Miizumi area introduced the rain shelter from Yamanashi Prefecture. He improved the tents and made a rain shelter so that he could avoid having his cherries spoiled by the heavy rains during the rainy season. Many farms changed their cherry varieties from "Napoleon," which was used for canning to "Satohnishiki," for eating. The farms reacted quickly and started improving the cherry varieties for bulk shipping. They cooperated with the Miizumi agricultural cooperative and conducted cherry fairs in 1971, followed by the start of cooperative shipments in 1974.

As the cherry cultivation for bulk shipping developed, Sagae City became famous and had to deal with cherry picking and direct selling for the residents in Sendai
City and neighboring areas, along with the requests of some tour companies. Only a few farms allowed cherry picking at that time, and there was great demand from tour companies. The local officials of Sagae City sometimes asked farms that owned large cherry fields or cherry orchards along the main roads to allow tourists to pick cherries. As demand for agri-tourism in this area increased, local farmers began to recognize the importance of this concept. In the end, pick-yourown farms increased, and the Miizumi Cherry-Picking Group was organized in 1973 with 17 farm households. At that time, the agri-tourism cherry cooperative made pamphlets about cherry picking and distributed them to 3,000 places at some important stations in the Tokyo Metropolitan Area, Sendai City, Niigata City, and Fukushima City. To unite windows that accepted reservations and controlled tourists, a new division was established in the agricultural cooperative. Thanks to this division's efforts, the management of the cherry picking in this area is very systematic. 


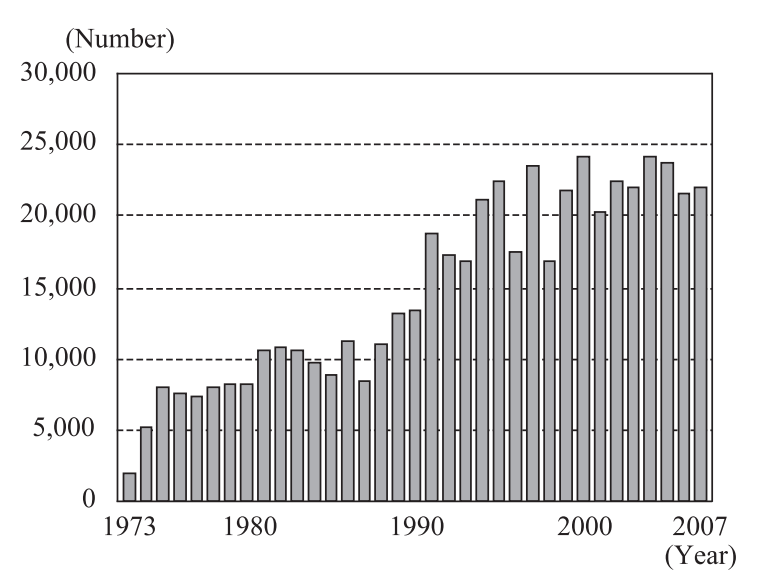

Figure 6. The number of tourists received by Miizumi Cherry Picking Group.

Source: Miizumi Cherry Picking Group.

\section{The number of tourists and attraction of tourists}

About 10,000 tourists visited the Miizumi CherryPicking Group every year during the 1980s (Figure 6). In the late 1990s, some tourism facilities were constructed by the agricultural cooperative to support cherry picking. Then, traffic condition such as opening of Yamagata Expressway and Gassan Road was improved. This led to an increase of tourists to a steady level, which is now more than 20,000 every year. For example, tour companies of Tokyo metropolitan area made tour plans including roadside station "Cherry land," hot spring and various events of this region and raised the interest of many tourists. Tour companies that offer cherry picking tours are as follows: Yomiuri Travel Service, Clubtourism, Kinki Nippon Tourist, JTB, and Hato Bus, all of which have their head offices in Tokyo. These companies create tours for tourists mainly from Tokyo (Table 1). "Other" tourists in Table 1, which accounts for $43.5 \%$ of all tourists, are individuals or families who came from Sendai City and neighboring areas by car. Thus, tourists can be divided into two types: 1) the groups of tourists taking packaged tours planned by a major tour company from the Tokyo Metropolitan Area and 2) individuals or families from Sendai City and neighboring areas. Mr. W, who is a leader of the Miizumi Cherry-Picking Group, visited Osaka, Nagoya, and Fukuoka city to promote cherry picking tours. This promotion was held to attract a wider group of tourists from a broader area in the farmers' off-seasons.

Moreover, the management center is an important facility for agri-tourism in the Miizumi area (Figure 7). It plays a multifaceted role, providing parking lots, a reception desk, and a direct-sales store for tourists. This center was built by Mr. W, who took advantage of the nation's Regional Agriculture Support Project in
Table 1. The number of tour companies and tourists using Miizumi Cherry Picking Group (2007)

\begin{tabular}{|l|r|}
\hline \multicolumn{1}{|c|}{ Tour companies } & Number of tourists \\
\hline Yomiuri Travel Service & 5,022 \\
\hline Club-tourism & 3,850 \\
\hline JTB Corporation & 1,104 \\
\hline Nokyo Tourist Corporation & 623 \\
\hline Kinki Nippon Tourist & 602 \\
\hline Hato Bus & 263 \\
\hline Meitetsu World Travel & 242 \\
\hline Yamako-kanko & 155 \\
\hline Niigata-kotsu & 106 \\
\hline Fukushima-kotsu & 104 \\
\hline Nippon Travel Agency & 89 \\
\hline Joban-kotsu & 89 \\
\hline Top tour & 9,617 \\
\hline Other ${ }^{1)}$ & 22,091 \\
\hline Total & \\
\hline 1) "Other" includes tour companies except for the above and & \\
\hline Source: Miizumi Cherry Picking Group. & \\
\hline
\end{tabular}
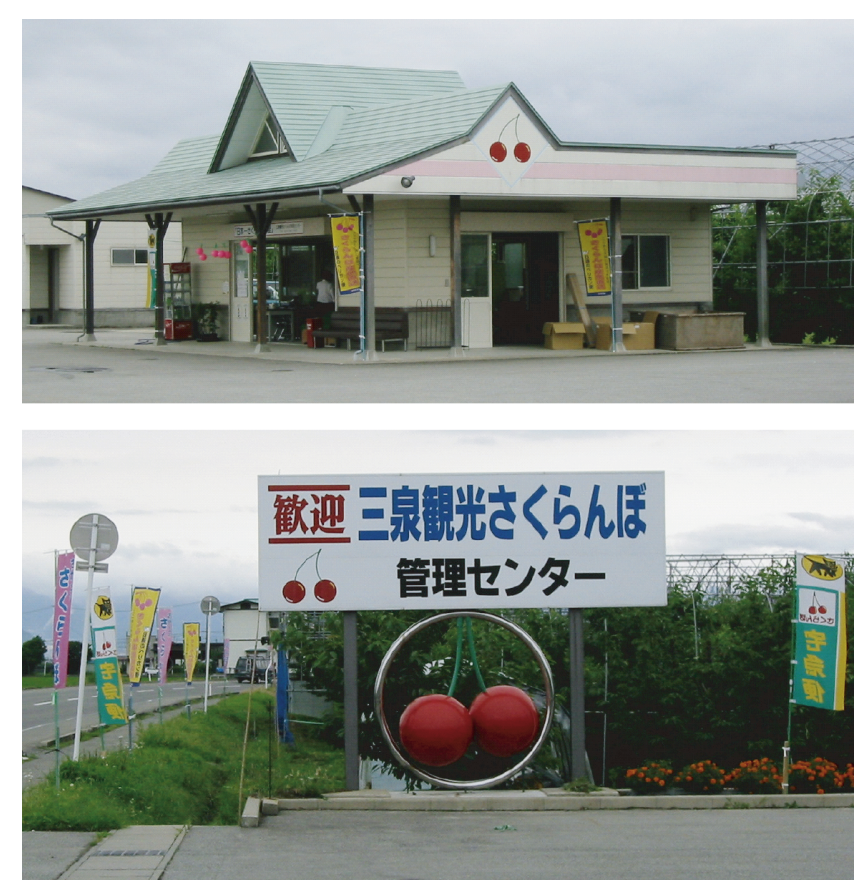

Figure 7. The management center of the Miizumi Cherry Picking Group.

Taken by the author, July 2007.

December 1998. The total cost was 41.05 million yen, of which $50 \%$ was covered by public subsidies. The management center accepts all the reservations of the tourists who want to visit the pick-your-own farms in the Miizumi area. The center divides tourists among the farms. Under this system, the farm households are 
requested to standardize the quantity of cherries they produce, and farm households can gain equal benefit per the amount of cherries grown by each farm. The cherries sold in the management center are collectively provided by members of the Miizumi Cherry Picking Group. As for the entrance fees of 1,200 yen, the agricultural cooperative takes $10 \%$ for group tourists and 5\% for individual tourists to manage the information desk, some events, and promotion activities. In some cases, entrance fees for the group tourists are sometimes discounted by $150-400$ yen.

\section{Cultivation types and selling methods}

Agriculture in the Miizumi area of Sagae City mainly consists of rice and cherry cultivation. According to Figure 5 , the cherries are cultivated widely on the natural levee, which is along the main roads and around residential areas. The paddy fields can be seen in the northern part of the settlement that is the back marsh. The introduction of a new variety of cherries is progressing in the Miizumi area and a new variety, named "Benishuho," has emerged in recent years. Twenty-six farms cultivate cherries in greenhouses with heating systems. These efforts to introduce new facilities and varieties have resulted in the dispersion of the labor force and improvement of work efficiency. The Census of Agriculture in 2005 showed that there were 142 commercial farm households in the Miizumi area, of which 15 are working full-time. Among part-time farm households, 43 are engaged mainly in farming. In 2005, the farm households that produced only fruit totaled 71 ; the households that made mainly fruit as well as rice numbered 34; and the households that produced mainly rice in addition to fruit came to 14. Fruit is the main product for many farm households in the Miizumi area. The farm households that provide fruit for the official and unofficial markets (e.g., direct selling) amount to 140 (98.6\%), and more than $90 \%$ of their cultivated acreage for fruit is for cherries. Compared with Sagae City (60\%), the percentage of the Miizumi area shows that cherries are regarded as the most important product by the farm households in this area. Thus, although the farm households in Miizumi that provide fruit mainly for selling only total $140,9.1 \%$ of all farm households $(1,536)$ in Sagae City saw their sales reach 107 tons (or $15.4 \%$ of total sales) for the agricultural cooperative.

At the cherry fair promoted by the agricultural cooperative, the most prized cherry and three-eighths of the gold- and silver-class cherries in the simple packaging section were produced by the farm households in the
Miizumi area. In addition, in the special packaging section, the most prized cherry and one-half of the gold- and silver-class cherries were provided by the farm households in the Miizumi area. The average price of cherries in the Miizumi area is more than 2,000 yen per kilogram, compared with the price of 1,600 yen at the agricultural cooperative. This means that the cherries made in the Miizumi area are highly evaluated by marketers.

Most part-time farm households that mainly provide cherries grow their cherries by themselves and entrust others with rice cultivation. The Miizumi rice center is the receiver for the rice cultivated by these part-time farm households. This center receives the rice cultivated on 30ha and supports the elderly farmers in the area. According to the Census of Agriculture in 2005, 56 parttime farm households in the area entrust rice cultivation, and 12 full-time farm households receive rice cultivation. The farm households in the Miizumi area manage their agriculture around cherry farming. The part-time farm households and the elderly farmers entrust rice cultivation. The farm products for sale, however, are mainly cherries.

\section{Classifications of farms and characteristics of farm management}

In 2007, there were 15 farms in the Miizumi CherryPicking Group. Among them, 11 farms managed picking, direct sales, and the door-to-door deliveries of cherries, and the other 4 farms managed only direct sales and the door-to-door deliveries (Table 2). The term "tourism type" refers to the former, and the latter refers to "directselling type."

In 2005, the average cultivated acreage of the commercial farm households in the Miizumi area was $120.1 \mathrm{a}$, and their fruit acreage was $33.9 \mathrm{a}$. In contrast, the cultivated acreage of tourism farms was $134.7 \mathrm{a}$, and their fruit acreage was $65.3 \mathrm{a}$, twice as much as that of commercial farm households. This is more than the average for the commercial farm households in the Miizumi area. Farms that engage in agri-tourism own large cultivated acreage that is more than the average commercial farm households, and a high proportion of their cultivation acreage is used for fruit. Eleven farms of tourism type have been operating pick-your-own farms for 35 years, since the establishment of cherry picking group in 1973. Four farms of direct-selling type were not original proponents of agri-tourism. They joined the agri-tourism movement from 2000 after retiring from off-farm jobs. Since their farms face the main roads, they 
Table 2. Characteristics of tourism farms in the Miizumi area of Sagae City, Yamagata Prefecture (2007)

\begin{tabular}{|c|c|c|c|c|c|c|c|c|c|c|c|c|c|c|c|c|c|}
\hline \multirow{3}{*}{ Type } & \multirow{3}{*}{ 㨱 } & \multicolumn{12}{|c|}{ Farm family members by age group ${ }^{a)}$} & \multicolumn{4}{|c|}{ Cultivated acreage (are) } \\
\hline & & \multicolumn{2}{|c|}{$30-39^{b)}$} & \multicolumn{2}{|c|}{$40-49$} & \multicolumn{2}{|c|}{$50-59$} & \multicolumn{2}{|c|}{$60-69$} & \multicolumn{2}{|c|}{$70-79$} & \multicolumn{2}{|c|}{$80-$} & \multicolumn{2}{|c|}{ Cherries $^{\mathrm{d})}$} & \multirow{2}{*}{ Rice } & \multirow{2}{*}{ Total } \\
\hline & & M & $F^{c)}$ & M & $\mathrm{F}$ & M & $\mathrm{F}$ & M & $\mathrm{F}$ & M & $\mathrm{F}$ & M & F & Rs & Gh & & \\
\hline \multirow{11}{*}{ Tourism type } & 1 & & & (a) & (a) & & & & (a) & () & & & & 100 & 30 & 100 & 230 \\
\hline & 2 & $\triangle$ & $\triangle$ & & & & & (0) & $\diamond$ & & & & & 100 & 20 & 300 & 400 \\
\hline & 3 & & & $\triangle$ & (a) & & & ()) & () & & & & & 100 & & 180 & 280 \\
\hline & 4 & & & & & (a) & (a) & & & (a) & & & & 80 & & 60 & 140 \\
\hline & 5 & & & & & $\triangle$ & & & & (a) & (a) & & & 70 & & 100 & 170 \\
\hline & 6 & & & $\triangle$ & & & & & (a) & (a) & & & & 70 & & 60 & 130 \\
\hline & 7 & & & $\triangle$ & (a) & & & & & (a) & (a) & & & 60 & & 60 & 120 \\
\hline & 8 & $\triangle$ & $x$ & & & & & (a) & (0) & & & & & 60 & & - & 60 \\
\hline & 9 & & & & & $\triangle$ & $\triangle$ & & & & (a) & & & 50 & & - & 50 \\
\hline & 10 & & & $\triangle$ & (a) & & & & & & (a) & & & 50 & & - & 50 \\
\hline & 11 & & & & & $\triangle$ & & & & & & (a) & & 20 & & - & 20 \\
\hline \multirow{4}{*}{$\begin{array}{l}\text { Direct-selling } \\
\text { type }\end{array}$} & 12 & & & & & & & & & (a) & (a) & & & 70 & & 200 & 270 \\
\hline & 13 & & & & & $\triangle$ & & & & (a) & (a) & & & 40 & & - & 40 \\
\hline & 14 & & & & & ()) & $\triangle$ & & & & (a) & & & 40 & & - & 40 \\
\hline & 15 & & & & & & & (a) & (2) & & & & & 20 & & - & 20 \\
\hline
\end{tabular}

operate direct-sales stores. Most of the tourism type are managed by elderly couples between 60 and 70 years old. Sometimes, their family members who live with them and are engaged in off-farm jobs provide support when needed. Most of these households are full-time farmers, too. Although direct-selling type has similar characteristics, they do not have sufficient family labor. Therefore, they tend to choose direct-selling and door-todoor delivery, which does not need a labor force.

The second-generation members of tourism farm families live with the householders and have off-farm jobs. However, there are some second-generation family members who prepare to take over their parents' farms and cherry cultivation. They join the Miizumi Cherry Club organized by the farm households and get training in cultivation techniques. For example, the sons on farm 1 , who are engaged in farm labor now, and on farms 3,5 , and 9, who have non-agricultural jobs, are the expected successors.

For many farms, "Satohnishiki" is the most popular cherry variety, and $60 \%$ to $70 \%$ of the farm household use this seed. "Takasago" and "Napoleon" varieties have long been cultivated in this area. Agricultural cooperatives promote the "Benisayaka" and "Benishuho" varieties to increase work efficiency. These varieties can be harvested before and after the crop time of "Satohnishiki."

The core of their selling methods is direct selling and door-to-door delivery. For instance, the selling method of farm 3 consists of $20 \%$ cherry picking, $48 \%$ directselling (in front of the orchard), and $32 \%$ of door-todoor delivery. Many door-to-door deliveries are ordered by customers living in the Tokyo Metropolitan Area. In addition, about $10 \%$ of the rice is sold through orders from the customers who have ordered the cherries for door-to-door delivery. Farm 8 is shipping about 10\% of its cherries to the agricultural cooperative, because this farm household is small and tries to avoid the risk of cancellation by the tourists. Door-to-door-delivery is the most important selling method and accounts for $45 \%$ of total sales. The number of customers was increased by the pick-your-own farms, and those customers' orders for door-to-door delivery enhanced the importance of this method. Direct-selling type has similar tendencies, and they sell the cherries by methods of direct selling and door-to-door delivery. Neither tourism type nor directselling type can accept all the orders from the tourists. The Miizumi Cherry Picking Group buys cherries from the cherry shipment group in the Miizumi branch office of Sagae-nishimurayama Agricultural Cooperative to compensate for the lack of the cherries for the tourists. 
In this case they pay the marketing cooperative a price that is $10 \%$ above the market price at that time, in order to obtain the cherries. Thus, it is necessary that the relationship between tourism farms and non-tourism farms is well maintained.

\section{Construction of Cooperation System and Influence to Regional Agriculture}

\section{Diversification of the menus of cherry picking}

Tourism farms in the Miizumi area offer three kinds of cherry picking to tourists (Table 3). The first is cherry picking in the greenhouses with heating systems, which are open from late May. The price is relatively expensive, from 2,000 yen to 3,500 yen for one adult for 30 minutes. This range is related to additional fuel costs. The second kind is picking cherries in open field from early June. For this service, the price is set at 1,200 yen per adult, including all the cherries you can eat in 60 minutes. The price for the special version of this service is 1,500 yen that includes a 300 -gram souvenir package of cherries. Three deluxe versions are also available. In the cherry picking group, farms 1 and 3 offer qualified cherry picking, which includes the picking of "Satohnishiki" cherries with above $14 \%$ sugar content. Farmers also offer the picking of the giant cherry tree, which makes use of the cherry trees that are more than 50 years old. Farmers also offer Super VIP Cherry Picking, which prepares L-size or bigger cherries of the highest quality and a sugar content of more than $18 \%$. Farmers are prepared to cope with the special requirements of tourists who demand the highest quality or who want such classic varieties as
"Napoleon" or "Takasago," prevalent before the spread of "Satohnishiki".

In the Miizumi Cherry Picking Group, only farm 1 offers cherry picking in greenhouses. In cases of accidents with cherries in open fields, such as the unsatisfactory growth caused by unstable weather, farmers allow the tourists to enter the greenhouses of farm 1 as an alternative. In this situation, members of the Miizumi Cherry Picking Group have to pay a deficit charge to farm 1. These kinds of measures are very important to avoid the risk of degrading their reputation by cancellation or insufficient cherry picking. In 2007, these measures were applied three times for 204 tourists in five groups. These measures were applied by the Miizumi Cherry Picking Group because the association was responsible for the tourists' satisfaction and to protect its reputation as the sole agent of the agri-tourism of this area, even though the group incurred additional costs.

\section{Leaders' strategy of Miizumi Cherry Picking Group}

The farms of the Miizumi area have had stable management and high profits from cherry cultivation. Elderly farmers have handed down their agricultural techniques to the younger generation, and have been successful in preserving the high reputation of cherries in Miizumi. In cherry cultivation, big differences in cultivation techniques among farmers are unavoidable. These differences directly reflect the qualities of the cherries even in the same local area (Murata 1995). This issue has been an important point for maintaining the cooperative system of common quality checks and shipping. In the Miizumi area, a joint shipping system via

Table 3. Description of agri-tourism in Miizumi Cherry Picking Group (2007)

\begin{tabular}{|c|c|c|c|c|}
\hline & Item ${ }^{\text {a) }}$ & Period & The entrance fee ${ }^{b)}$ & Variety and condition \\
\hline \multirow{3}{*}{ 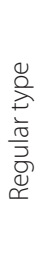 } & $\begin{array}{l}\text { Cherry picking } \\
\text { (Greenhouse) }\end{array}$ & $\begin{array}{l}\text { May } 20- \\
\text { beginning of June }\end{array}$ & $\begin{array}{l}2,000-3,500 \text { yen } \\
\text { less than } 30 \text { minute }\end{array}$ & Variety: "Satohnishiki" \\
\hline & $\begin{array}{l}\text { Cherry picking } \\
\text { (Open Field) }\end{array}$ & \multirow{2}{*}{$\begin{array}{l}\text { Beginning of June-- } \\
\text { the middle of July } \\
\text { (it may start from the } \\
\text { end of May) }\end{array}$} & $\begin{array}{l}1,200 \text { yen }(\text { Adult)/ } \\
1,000 \text { yen }(\text { Small child) }\end{array}$ & $\begin{array}{l}\text { Variety: "Benisayaka", "Satohnishiki", "Napoleon" and } \\
\text { "Benishuho" }\end{array}$ \\
\hline & $\begin{array}{l}\text { Cherry picking with Souvenirs } \\
\text { (Open Field) }\end{array}$ & & 1,500 yen- & $\begin{array}{l}\text { Variety: "Benisayaka", "Satohnishiki", "Napoleon" and } \\
\text { "Benishuho" }\end{array}$ \\
\hline \multirow{3}{*}{ 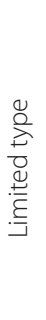 } & $\begin{array}{l}\text { Cherry picking } \\
\text { (High qualities 1) }\end{array}$ & $\begin{array}{l}\text { The middle of June-- } \\
\text { beginning of July }\end{array}$ & $\begin{array}{l}1,700 \text { yen }(\text { Adult)/ } \\
1,500 \text { yen }(\text { Small child) }\end{array}$ & $\begin{array}{l}\text { Condition: "Satohnishiki" in which coloring is good at a } \\
\text { large cherry, } 14 \text { or more sugar contents/ } \\
\text { Only for group tour parties }\end{array}$ \\
\hline & $\begin{array}{l}\text { Cherry picking } \\
\text { (High qualities 2) }\end{array}$ & $\begin{array}{l}\text { The middle of June-- } \\
\text { end of June }\end{array}$ & $\begin{array}{l}2,000 \text { yen }(\text { Adult)/ } \\
1,800 \text { yen }(\text { Small child) }\end{array}$ & $\begin{array}{l}\text { Condition: "Satohnishiki" more than L ball, } 18 \text { sugar } \\
\text { contents or more/ } \\
\text { Reservation required }\end{array}$ \\
\hline & $\begin{array}{l}\text { Cherry picking } \\
\text { (Old trees and Breeds) }\end{array}$ & $\begin{array}{l}\text { The middle of June-- } \\
\text { end of June }\end{array}$ & $\begin{array}{l}1,500 \text { yen }(\text { Adult)/ } \\
1,300 \text { yen }(\text { Small child) }\end{array}$ & $\begin{array}{l}\text { Condition: big trees more than } 50 \text { years old/ } \\
\text { Only for group tour parties }\end{array}$ \\
\hline
\end{tabular}

a) As other items: Making jam using "Napoleon", cherry picking of only "Benishuho."

b) Regular time of cherry picking and free eating is less than 60 minute.

Source: Miizumi Cherry Picking Group. 
the agricultural cooperative has been in place since the 1970s. The motivation of farmers in this area to improve techniques has been very high. For example, farmers 70 to 80 years old (farms 4 and 7) organized a study group for fruit cultivation in the 1960s. Through this group, they exchanged information and techniques. They even exchanged detailed techniques for pruning the fruit trees, which has a big influence on the growth of the trees and the quality of the products, with the younger generation households (farms 1, 3, and 6) (Figure 8). Under the instruction of the senior farmers, the younger generation farmers at that time improved their techniques for cherry cultivation and were able to supply high-quality cherries to the market. In the late 1960s, they started providing cherry picking and direct sales for visiting customers. In 1973, the Miizumi Cherry Picking Group was organized by the abovementioned farms.

In the 1970s, Mr. W of farm 3 organized the Miizumi Accepted Pruning Group. This group passed along cultivation techniques to all young farmers in the Miizumi area. They were afraid that different techniques among the local farm households might degrade the reputation of the area as a whole. Through the activities of this group, they tried to improve in many ways. They made a trustee system that supports the part-time farm households and old-aged farmers who lack the labor force needed for cherry cultivation. During these activities, the pairs with senior and junior members did cooperative work at the trustee farms. Through these joint efforts, they exchanged techniques and shared instructions among the members. In 2007 they accepted 80 trustee works for pruning about 10ha. Among these works, 60 were requests from the farm households in this area. The other 20 works were requests by the relatives or acquaintances who live in other areas in Sagae City as well as in the neighboring cities of Kahoku, Tendo, and Yamagata. For this work, a service charge of 1,500 yen per hour was paid by the clients. This project has two implications. First, it provides a side business during the agricultural off-seasons. Second, it is generally regarded as an important chance to promote the exchange of techniques.

Moreover, Mr. W became the technical advisor, together with Mr. K (the current chairperson of the Cherry Shipping Association of the Agricultural Cooperative) of the Miizumi Cherry Club, which was organized in 1990 to nurture agricultural successors in the Miizumi area and to promote the non-agricultural workers' entry to agriculture. Mr. W has instructed the young farmers and those non-agricultural workers who intend to be farmers through seminars on grafting and pruning trees (summer and winter), seminars on fertilizers and pesticides, the cherry fairs, and study tours. In the 1990s, just after the start of the Cherry Club, the prizewinners in the cherry fair were usually the same from year to year. However, recent winners have changed every year. This proves that the cultivation techniques of the young farmers in

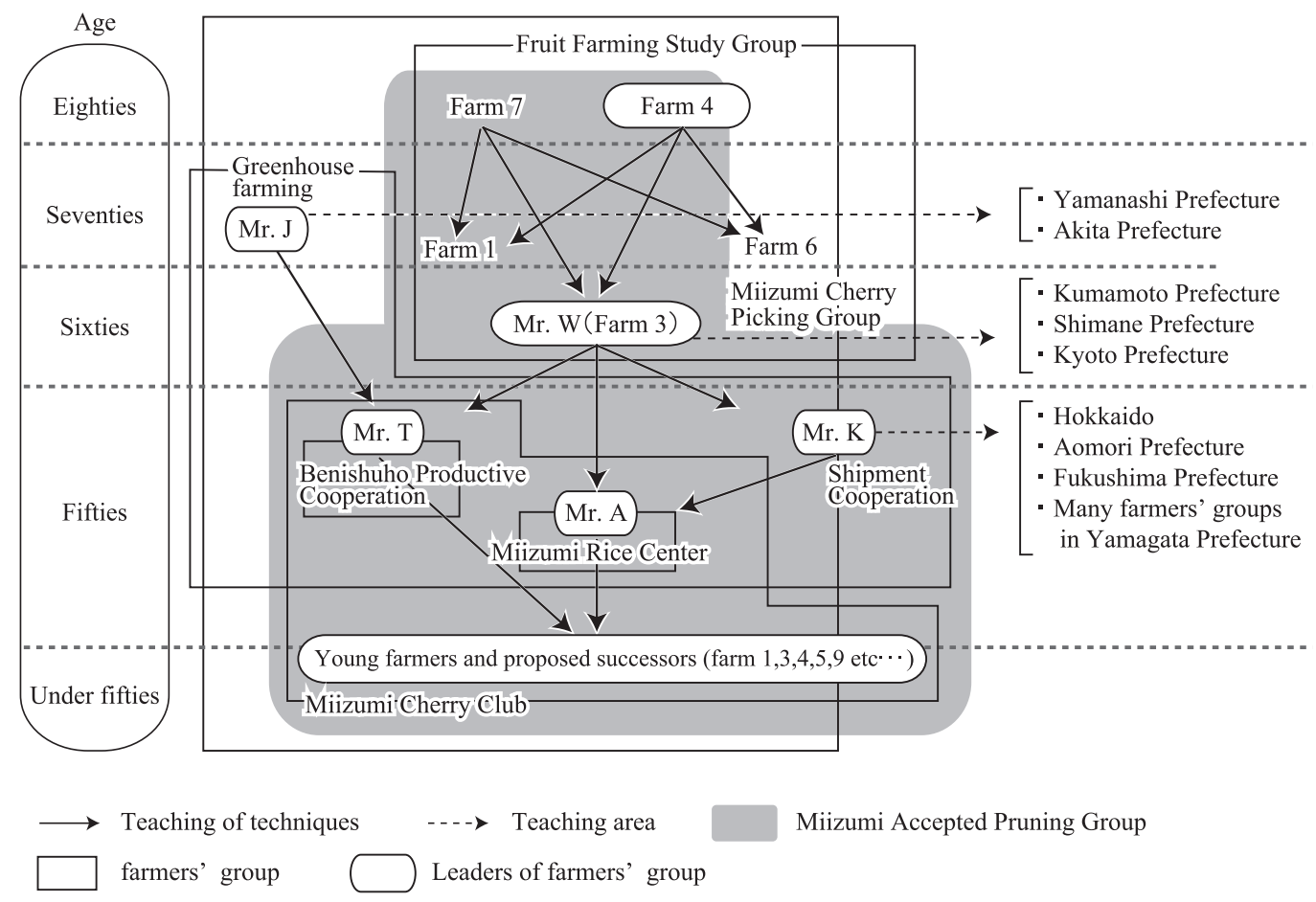

Figure 8. Diffusion of cultivation techniques led by Mr. W in the Miizumi area of Sagae City, Yamagata Prefecture (2007). 
this area are stable at a high level. Mr. T, who received instruction from Mr. W in the 1990s, was the chairperson of the Cherry Shipping Association of the Agricultural Cooperative until 2006. Since 2007, he has been serving as the chairperson of "Benishuho" Production Association of Sagae City and has promoted this new variety. In 1994, Mr. A became the second chairperson of the Miizumi Cherry Club. Mr. A organized the Miizumi Rice Center in 2006, in cooperation with five full-time farmers in their 40s and 50s. Mr. A built a rice center through a governmental project. He is contracting $35 \mathrm{ha}$ of farms for 20 trustee farm households. He is also an important agent promoting the rice farming of this area.

At present, Mr. T and Mr. A, who were trained by Mr. W in the 1990s, are the technical advisors of the Miizumi Cherry Club and take care of the instructional activities. In 2007, the club had 31 members, including young farmers and non-agricultural workers who intend to be farmers. The breakdown of the members in terms of age is as follows: 4 members in their 20s, 4 members in their 30s, 9 members in their 40s, and 14 members in their 50s. Among the present members of the Miizumi Cherry Club, there are sons of the Miizumi Cherry Picking Group, farms 1 and 4 (the full-time farmers in their 40s and 50s). They also include the sons of the members of the Miizumi Cherry Picking Group, farms 3, 5 , and 9 , who have off-farm jobs. They receive instruction from Mr. T and Mr. A. It can be concluded that the technical traditions of cherry cultivation in the Miizumi area are maintained through the mutual efforts among tourism farms and non-tourism farms, from generation to generation. Mr. W, the chairperson of cherry picking group, has striven for the general development of agriculture of the area, which does not seem to be related directly to management of the pick-your-own farms. He thought that it was important to protect the reputation of the cherry-growing area as a whole. For this purpose, it is necessary for both the tourism farms, which have direct contact with tourists and consumers, and the nontourism farms to continue to supply high-quality cherries. Murayama Region including Sagae city is the largest cherry-growing area of Japan. Although many consumers recognized Yamagata as a cherry-growing area, they did not know the details. It is therefore necessary to appeal to the tourists to change their minds from a general image of the cherries of Yamagata to the specific images of cherries from Sagae or cherries from Miizumi. That is why Mr. $\mathrm{W}$ thought it was important to promote the levels of cultivation techniques of the cherry-growing farms in the Miizumi area. As a result of his efforts, the farmers are promoting comprehensive activity for agri-tourism and cherry shipping to the agricultural cooperative.

The cherries of Sagae City were selected by Yamagata Prefecture as "Yamagata Selections," which are specially recommended by the prefecture to outside customers. Among the Sagae cherries, the cherry from Miizumi received a special evaluation and is frequently used in formal events organized by the prefectural governor. These include promotion fairs of local products or meetings with the representatives from other prefectures. Furthermore, cherries of the Miizumi Cherry-Picking Group were introduced as the representative of Yamagata cherries on the webpage titled "The Gourmet in Nippon: Enjoying the trips and special foods," on the homepage of Club-Tourism (http//www.club-t. com/doraku/200805/index.htm). In this way, cherries from Miizumi are contributing much to the area's high reputation throughout Japan. Mr. W and Mr. K have been invited to demonstrate their techniques in such cherrygrowing areas as Hokkaido, Aomori Prefecture, and the mountain zones of Western Japan interested in starting cherry cultivation. These activities are not sporadic. They are invited by many of the cherry-growing areas and agricultural promotion organizations every year. This shows that cherry cultivation in Sagae City (the Miizumi area) is acquiring a high reputation among farmers and agricultural organizations in other prefectures. Moreover, their visits to those areas gave them additional chances to advertise the cherry cultivation of Sagae City or the Miizumi area, which further enables them to acquire a broader reputation.

\section{Expansion of direct selling to non-tourism farms}

The Miizumi Cherry-Picking Group has consisted of fixed households since it began in 1973. The group has hosted a good number of tourists since the 1990s. In 2000, 4 farms joined this group and started direct sales. The number of farms that allow cherry picking has not increased for 35 years. The general factors are as follows. The younger generation of farmers, who took over farm operation in the 1990s, preferred to introduce cherry cultivation in greenhouses with heating systems to bring about high profits. Some farms also added flower cultivation. In 2007, 26 farms were engaged in cherry cultivation in greenhouses. Among them, almost 50\% were full-time farmers in their 40s and 50s. For example, Mr. A entered agriculture after resigning from nonagricultural work. He said that he was keenly interested in the heating techniques that would enable him to ship early and to get higher sales prices. Those factors were the 
reasons why the younger-generation farmers (current $40 \mathrm{~s}$ and 50s) did not join agri-tourism.

It cannot be said that the non-tourism farms are not interested in transactions outside the wholesale markets. For example, the non-tourism farms receive quite a few orders of door-to-door delivery via their relatives and acquaintances. Direct selling is becoming the method of sales that can't be avoided for many farms. Here, I will summarize the types of management of non-tourism farms and their methods of sales. The management can be roughly classified into four types: 1) the type dealing only with cherries; 2) the type combining cherries, paddy rice, and livestock; 3 ) the type combining cherries and paddy rice; and 4) the type combining cherries, paddy rice, and flowers. The farm households that concentrate solely on cherries put an emphasis on greenhouse cultivation with heating, as the cherries are the only way to earn more income.

For example, Mr. K sells $60 \%$ of his open-field cherries through door-to-door deliveries, while $80 \%$ of his cherries from heated greenhouse cultivation, which earn a high price at the market, are sold through the agricultural cooperative (Figure 9). Mr. K won a prize from the agriculture minister at a management competition organized by the Ministry of Agriculture, Forestry and Fisheries. There is also another farmer who won a prize from the agriculture minister at a fair at the Ohta market of Metropolitan Central Wholesale Market. They contributed much to enhance the reputation of cherries of Sagae and Miizumi. These farms started their own websites, and they are actively engaged in door-todoor deliveries.

Among households in the combined type of cherries, paddy rice, and livestock, Mr. T sells all the products from his greenhouse cultivation through the agricultural cooperative. As for his open-field cherries, he sells $40 \%$ through door-to-door deliveries and 60\% through the agricultural cooperative. Furthermore, he sells 50\% of his rice production through the agricultural cooperative, and the remaining $50 \%$ to customers of the cherries. The cherry customers place orders for rice when the new rice harvest season comes. Mr. A of the combined type of cherries and paddy rice and $\mathrm{Mr}$. $\mathrm{R}$ of the combined type of cherries, paddy rice, and flowers sell $20 \%$ of their cherries via door-to-door delivery and $10 \%$ to $20 \%$ of their rice this way as well.

In this way, non-tourism farms have customers for direct sales of cherries. Even though they differ from tourism farms, it can be said that agri-tourism penetrated into the non-tourism farms because direct selling has been included in their overall sales. Actually, non-tourism farms sometimes comply with requests for cherry picking by acquaintances and relatives.

\section{Conclusion}

This study examined sustainable systems of agritourism in a cherry-growing area. In Sagae city, it was an

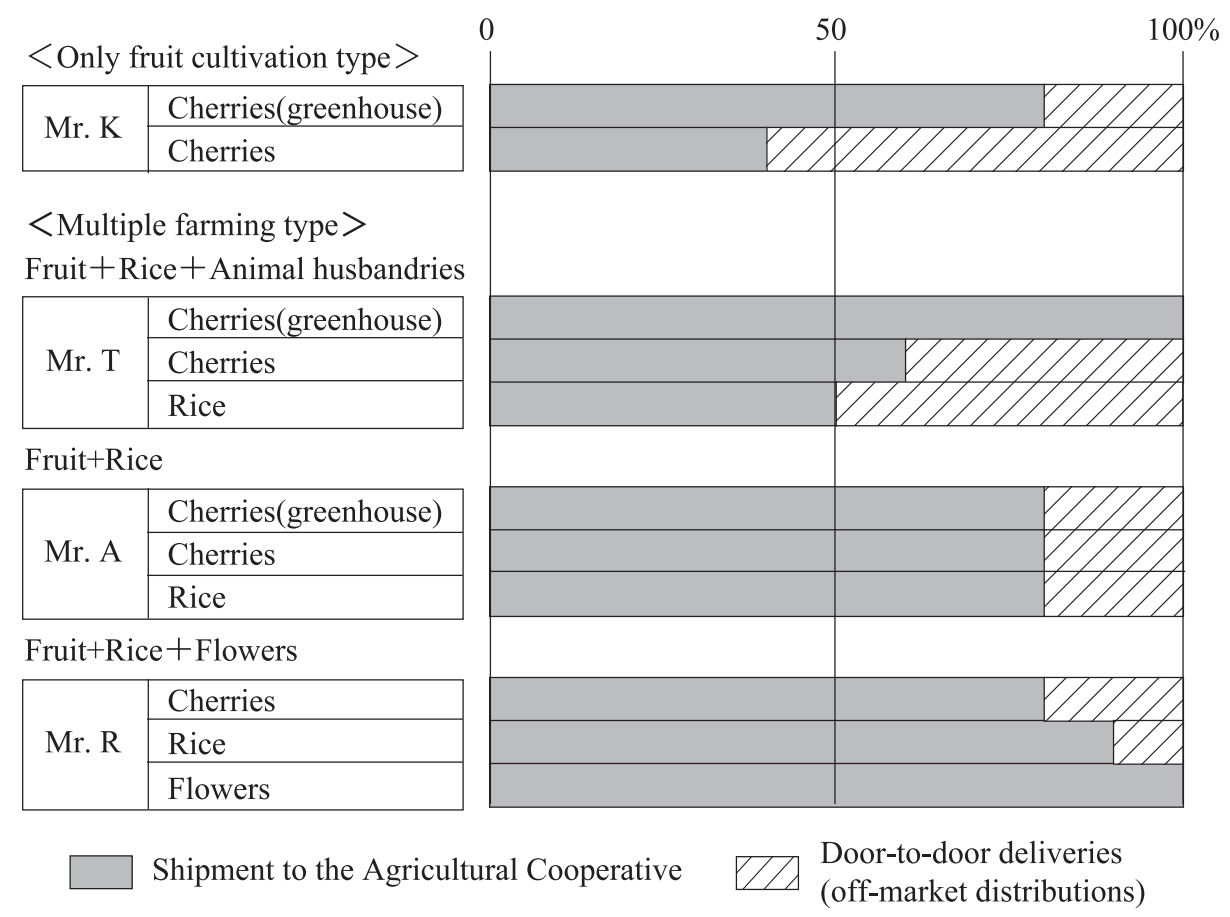

Figure 9. Selling methods of non-tourism farms in the Miizumi area of Sagae City, Yamagata Prefecture (2007). 
opportunity of agri-tourism that some farmers received cherry picking through a travel company of Sendai City in the latter half of the 1960s. Later, the other farmers recognized the size of the tourism demand. They organized a cherry picking group in the first half of the 1970s. In the 1980s, a window of agri-tourism was included in the agricultural cooperative to correspond to tourism demand and to unify the service and pricing of many pick-your-own farms. At the harvest time of the cherry, the agricultural cooperative organized a media focus on the cherry of Sagae City. This was to aim at the new business development of the market and the improvement of publicity. In addition, farms could reduce the burden on the operation side and perform advertising easily in order for the agricultural cooperative to have a window. All told, after the 1990s, the cherry picking group of the Miizumi area has gathered about 20,000 tourists every year. They prepare a menu of options in response to the needs of the tourist who wants to enjoy high-quality and old cherry varieties, and deal with diversification of the taste. When cherries for direct selling run short, they secure cherries through the Miizumi branch office of the agricultural cooperative. This shows the importance of a good relationship between tourism farms and other farms. Mr. W, the leader of cherry picking group, believed it was indispensable to the promotion of agritourism and regional agriculture to raise the evaluation of the cherry of the Miizumi area, regardless of agritourism. He organized the "Miizumi Accepted Pruning Group" and "Miizumi Cherry Club," and aimed for the training of successors in this area and the improvement of cultivation techniques. As a result, farmers won the highest awards in many competitive shows and contests, and the Miizumi area was evaluated as a growing area that cultivated cherries of high quality. This contributed to the development of regional agriculture including agritourism.

Comparing this result with other studies of agritourism using the cherry, Hayashi (2007) examined a case study of remote areas far from metropolis, and showed that the local government and local leaders promoted agri-tourism. In agri-tourism of remote areas, cooperation with events of local development by the administration, and enlightenment of local farmers were important roles of leaders. This paper recognizes the role of the farmers' leader, but it is differs in the point that adjustment with non-tourism farms and the agricultural cooperative is more important in their roles, in comparison with Hayashi (2007). In addition, Hayashi (2006) examined agri-tourism near the metropolis. He showed that a fall in "the ability to pull in tourists" of the agricultural cooperative promoted individual farm management. Minami-Alps City, Yamanashi Prefecture discussed in Hayashi (2006) approaches Tokyo metropolitan area and Nagoya metropolitan area. This area had locational conditions that could get many customers by the effort of each farmer. In this area, agri-tourism was a tool to stabilize individual farm management. There was little consideration to others in comparison with the case presented in this paper.

In a word, receptive attitude of non-tourism farms and the agricultural cooperative is necessary for the development of agri-tourism in a large growing area such as Sagae City. In that sense, it is very effective that cherry growers have deepened interchange through succession and sharing of cultivation techniques. This improved the publicity for the growing area, letting the public know that the high-quality cherry was supplied through various sales courses and contributed to the development of both wholesale market circulation and agri-tourism. The cherry harvest was sometimes unstable from year to year year, and there was a technical gap influencing quality in each farm (Murata 1995). Therefore, succession and the sharing of cultivation techniques in the growing area proved indispensable. It was important for the promotion of regional agriculture that the publicity of cherries in Sagae City improved.

In terms of handing down cultivation techniques, Umeda (2008) examined the role of regional learning systems in the innovation of new technologies. As he stated, most of the knowledge to support agriculture was tacit knowledge gained through experience, further, in Japan, a traditional succession method through a relationship such as between parent and child has been maintained. Therefore, the opportunity for a new entrant to acquire tacit knowledge was extremely scant. In addition to the old knowledge tradition system of management succession between father and son, it is necessary to build the system that can properly hand down the latest technology and know-how to the next generation. Like the indication of Umeda (2008), in this paper, the regional learning system led by the local leader enabled highly advanced technical acquirement for many farmers, and contributed to the maintenance of regional agriculture. Farmers had tolerant minds for various values of farm management, because the technical succession was accomplished across the difference of the sales system. As a result, the symbiosis between tourism farms and non-tourism farms could be built. 


\section{Acknowledgements}

I would like to express my most sincere gratitude to Professor Akira Tabayashi of University of Tsukuba, for his valuable comments and encouragement. My special thanks are also due to all those people who provided me with valuable materials and information in my field survey. I would like to express my deepest gratitude to them. In creating English, I received the cooperation of Professor Noritaka Yagasaki at Tokyo Gakugei University and Dr. Thapa Rajesh Bahadur at University of Tsukuba. This paper is a part of my doctoral dissertation submitted to the graduate school of life and environmental sciences, University of Tsukuba. The abstract was presented at the 2008 spring conference of the Association of Japanese Geographers.

\section{Notes}

1. According to Keane et al. (1992), the terms that have described tourism in rural areas are varied, and they are used in different meanings with each country, and are not monolithic. According to Robinson (1990), the action patterns of tourists in rural villages also differ in each country, and differences of recognition and evaluation of people have influenced rural aesthetics.

2. Certainly the demand of tourism in rural areas existed before the high economic growth period from the 1960s to 1970s. The farm guest houses of Mt. Hakuba, which began in the late Taisho Era, are good examples. However, these were different from the present ones, because farmers at that time made the mountaineer and the skiing visitor stay and received remuneration as mountain guides (Ishii 1970).

3. Green tourism is generally defined as the "exchange between urban and rural people based on the farm guest houses and the farm experiences" in Japan. However, green tourism in Europe includes the concept of environment friendly "green" and means that it does not give load to environment and maintains the balance of the regional ecosystem (Yokoyama 1998).

4. Entrepreneur means an innovator of a new industry (Drucker 1985). In the agricultural field, it is the farmer who opens an original market and a new operation.

5. The cherry land is managed by the semi-public sector. In establishment, both Sagae City and the Sagae-Nishimurayama Agricultural Cooperative invested 15 million yen, Yamagata Prefecture invested 5 million yen, and seven companies within the prefecture (like the Yamagata Bank and the Yamagata traffic) also invested.

6. Since Mr. W was engaged in agriculture at the age of 18 in 1958, he has led agriculture of the Miizumi area. From 1973 to 1993, he supported the Miizumi Cherry Picking Group as the director, and he has played an important role as a leader of the group since 1994 .

\section{References}

Akitsu, M. 2007. Karuchuraru taan suru inaka: Ima doki nouson shakai kenkyu gaido (Countryside under cultural turn: An introduction to the present study on rural societies). In Seibutsu shigen mondai to sekai (Problems of biological resources and the world), ed. K. Noda, 147-178. Kyoto: Kyoto Daigaku Gakujutsu Shuppankai. (J)

Bowler, I. R. 1981. Self-service down on the farm. Geography 66: 147-150.

Bowler, I. 1982. Direct marketing in agriculture: A British example. Tijdschrift voor Economische en Sociale Geografie 73: 22-31.

Bryant, C. R. and Johnston, T. R. R. 1992. Agriculture in the city's countryside. London: Belhaven Press.

Caballe, A. 1999. Farm tourism in Spain: A gender perspective. Geojournal 48: 245-252.

Clout, H. D. 1972. Rural geography: An introductory survey. Oxford: Pergamon Press.

Drucker, P. F. 1985. Innovation and entrepreneurship. New York: Harper \& Row Publishers.

Fujime, S. and Yang, Y. 2004. Pekin shi ni okeru kankou nouen no tenkai to seiritsu youken (Development and formation of pickyour-own farm in Beijing City). Ehime no Chiri 17: 50-63. (J)

Gilg, A. W. and Battershill, M. 1999. The role of household factors in direct selling of farm produce in France. Tijdschrift voor Economisce en Sociale Geografie 90: 285-295.

Hall, C. M. and Page, S. J. 2006. The geography of tourism and recreation: Environment, place and space, 3rd ed. London: Routledge.

Haseyama, T. 1988. Sougou nougyou kenkyu sousho 13 Chiiki nougyou tenkai no ronri: sono shutaironteki kousatsu (The logic of regional agriculture development). Tokyo: Meibun-Shobo. (J)

Hayashi, S. 1994. Diffusion of a new strawberry variety, Nyoho, in Tochigi Prefecture. Geographical Review of Japan 67A: 619637. (JE)

Hayashi, T. 2006. The significance of pick-your-own farm management in Nishino, Shirane District, Minami-Alps City. Proceedings of the 2006 Annual Meeting of the Human Geographical Society of Japan: 76-77. (J)

Hayashi, T. 2007. Development factors of agri-tourism in the Nagawa District, Nanbu Town, Aomori Prefecture: Role of local leaders. Geographical Review of Japan 80: 635-659. (JE)

Hayashi, T., Kanda, M., Takahata, M., Watanabe, Y. and Uchikawa, T. 2004. Souma shi wada chiku ni okeru kankou ichigoen keiei to nougyou no iji (Pick-your-own strawberry farm operation and sustainability of agriculture in Wada Area, Soma City). Shizen to Kurashi 11: 55-74. (J)

Hirayama, K. 1972. Nougyou no shinkinou to kankou nougyou (New agricultural features and agri-tourism). Nougyo to Keizai 38(10): 17-23. (J)

Iguchi, A., Tabayashi, A. and Waldichuk, T. 2008. Commodification of rural spaces in the stone-wall strawberry region: A case study of Zo village in Shizuoka City. The New Geography 56(2): 1-20. (JE)

Ilbery, B. W. and Bowler, I. 1998. From agricultural productivism to post-productivism. In The geography of rural change, ed. B. Ilbery, 57-84. Harlow: Longman. 
Ishii, H. 1970. Some considerations on the forming process of Minshuku region in Japan. Geographical Review of Japan 43: 607-622. (JE)

Katori, E. 2003. Nousanson shakai no saihen to gurin tsurizumu no kanousei: Kyouto fu Miyama chou no kankou nouen ewa rando no torikumi kara (Reorganization of rural society and possibility of green tourism). In Kankou to kankyou no shakaigaku (Sociology of tourism and environment), ed. A. Furukawa and M. Matsuda, 53-78. Tokyo: Shinyosya. (J)

Kawahara, N. 1996. Kyouto fu ni okeru kankou rekurieishon gata nogyou: Yawata shi no kankou nouen wo chushin ni (Agritourism in Yawata City, Kyoto Prefecture). Kyoto Chiiki Kenkyu 11: 64-75. (J)

Keane, M. J., Briassoulis, H. and van der Stratten, J. 1992. Rural tourism and rural development. In Tourism and the environment: Regional, economic and policy issues, environment and assessment, Vol. 2, ed. H. Briassoulis, and J. van der Stratten, 43-56. Dordrecht: Kluwer.

Kikuchi, T. 1997. Kantou chihou niokeru toshi-nouson kouryuu no sonzaikeitai: Gurin tsurizumu no shoruikei to sono sonzaiigi (Possibility of urban and rural interaction in the Kanto Region). Area Gunma 4: 1-13. (J)

Kikuchi, T. 2008. Potential development of geographical studies on rural tourism with the adoption of the research framework of food tourism. Geographical Space 1: 32-52. (JE)

Koike, A. 2002. The development of tourist farms in Chiyodamachi, Ibaraki Prefecture. Annals of the Ibaraki Geographical Society 3: 1-17. (J)

Kudo, J. and Hirai, T. 1998. Kankou nougyou wa kandou no dorama: JA Sagae Nishi-murayama kankou nougyou kachou Kudo Junichi hunsenki (Agri-tourism is a drama of impressions). Tokyo: Ie no Hikari Kyoukai. (J)

Lane, B. 1994. What is rural tourism? In Rural tourism and sustainable rural development, ed. B. Bramwell and B. Lane, 7-21. Clevedon: Channel View Publications.

Matsuda, S. 1973. Hokushin chihou ni okeru ringo saibai chiiki no henyou(Transformation of apple-growing area in the Hokushin District). The Geographical Report (Chirigaku Houkoku) 41/42: 31-37. (J)

Matsumura, N. 1982. Changes of cherry-growing region both with production adjustments of rice cultivation and with imports of foreign fruits. Kumamoto Journal of Culture and Humanities (Kumamoto Univesity) 8: 1-34. (JE)

McGehee, N. G. and Kim, K. 2004. Motivation for agri-tourism entrepreneurship. Journal of Travel Research 43 : 161-170.

McGehee, N. G., Kim, K. and Jennings, G. R. 2007. Gender and motivation for agri-tourism entrepreneurship. Tourism Management 28 : 280-289.

Miizumi Sonshi Hensan Iinkai 1971. Miizumi sonshi 1 (History and topography of Miizumi Village). Sagae: Miizumi-mura. (J)

Miyatake, K. 2007. Daikibo inasaku keiei no keiei kakushin to chiiki nougyou (Management innovation of large-scale rice-growing farms and regional agriculture). Tokyo: Nourin Tokei Kyoukai. (J)

Murata, K. 1995. Development of the mail-order farm-fresh produce business: A case study of the parcel postal delivery of cherries in Yamagata Prefecture. Geographical Review of Japan 68A: 367-386. (JE)
Nagaoka, A. 1990. Nousan kakoushihon to chiikishakai: 1960 nendai no Yamagatabonchi niokeru tenkai (capital of processing agricultural products and local community). In Chirigaku to Shakai (Geography and society), ed. K. Sawada, 259-267. Tokyo: Tokyo-shoseki. (J)

Nakajima, N. 1996. Nouson kankou to kankou nougyou (Rural tourism and agri-tourism). In Kankou kaihatsu to chiiki shinkou: gurin-tsurizumu kaisetsu to jirei (Tourism development and local promotion), ed. T. Wakita and T. Ishihara, 99-106. Tokyo: Kokon-shoin. (J)

Nakayama, A. 1999. Shizen kyuyouson seido ni okeru kankou nouen no seibi to sanson chiiki no kankouchika: Chiba ken Kimitsu shi Seiwa chiku wo jirei toshite (Maintenance of pick-your-own farm operation and development of mountain village area under 'shizenkyuyouson'). Geographical Reports of Chiba University 10: 31-40. (J)

Nakayama, A. 2000. Tourism development and regional promotion in 'shizenkyuyouson': A study of Nakatsugawa district in Iide town, Yamagata Prefecture. The Human Geography (Jimbun Chiri) 52: 372-384. (JE)

Nihei, T. 1998. Maintaining of horticultural management and technical innovation: A case study of Asahi-shi, Chiba Prefecture. Geographical Review of Japan 71A: 661-678. (JE)

Ohe, Y. 2003. Wagakuni ni okeru nouson tsurizumu no igi to kadai (Significance and problem of rural tourism in Japan). In Kanko no aratana chouryu (A new wave of tourism), ed. The Japan Society for Interdisciplinary Tourism Studies, 3-20. Tokyo: Dobunkan-Shuppan. (J)

Ohe, Y. 2005. Evaluating rural tourism activity by farmers retired from non-farming jobs: A multifunctional perspective. The Technical Bulletin of Faculty of Horticulture, Chiba University 59: 97-106. (JE)

Oizumi, K. 1996. On the role of leading farmers and farm management growth. Japanese Journal of Farm Management 34(3): 32-41. (J)

Robinson, G. M. 1990. Conflict and change in the countryside. London: Belhaven Press.

Sagae Shishi Hensan Iinkai 2007. Sgae shishi gekan kindaihen (History and topography of Sagae City). Sagae: Sagae-shi. (J)

Saito, Y., Nakamura, O. and Kinoshita, I. 1998. A study on the present situation of "agricultural tourism" and its evaluation: A case study in Aichi Prefecture. The Technical Bulletin of Faculty of Horticulture, Chiba University 52: 103-113. (JE)

Sharpley, R. and Sharpley, J. 1997. Rural tourism: An introduction. London: International Thompson Business Press.

Suda, S. and Ishigaki, H. 2001. The development process and management system of green tourist organizations. Japanese Journal of Farm Management 39(1): 37-47. (J)

Sukeshige, T. 1990. Kaduno bonchi ni okeru kankou ringo en chokubai ten no tenkai to sono mondaiten (Development and problem of pick-your-own apple farm and farm shop in the Kaduno basin). Rissyo Daigaku Daigakuin Nenpou 7: 87-103. (J)

Suzuki, H. 1999. Shizuoka ken ni okeru ichigo gari kankou nouen no hatten katei: Shizuoka shi Kunou to Izunagaoka machi Ema no hikaku (Development process of pick-your-own strawberry farm in Shizuoka Prefecture). Geographical Reports of Chiba University 10: 51-60. (J) 
Tabayashi, A. 1994. Changes in distribution of tulip bulb cultivation on the Kurobe alluvial fan. Geographical Review of Japan 67A: 437-460. (JE)

Tachikawa, M. 2005. Post-productivist transition of rural Japan and transformation of its social representation. Annual Bulletin of Rural Studies 41: 7-40. (JE)

Takahashi, M. 1998. The rural as space to social representation of rural space: Notes on social construction of rurality-I. Studies in Informatics and Sciences 7: 97-117. (JE)

Takahashi, M. 1999. Post-productivist countryside, commodification and rural planning: Notes on social construction of rurality-II. Studies in Informatics and Sciences 9: 79-97. (JE)

Tanabe, K. 1985. Nouson chiiki no rekurieishon chi ka ni tsuiteno ichikousatsu: Kobe-shi kitaku arinomachi Jirou no ichigo gari wo rei toshite (Development of recreation in rural area). Humanities Review (Kwansei Gakuin University) 35(3): 137163. (J)

Tanabe, K. 1988. A study of recreational farm: Taking the example of Kasuga-cho, Hikami-gun, Hyogo Prefecture. The Human Geography 40: 355-367. (J)

Tanno, A. 1974. Changes of the Chichibu district caused by construction of private railway. Geographical Review of Japan 47A: 498-510. (JE)

Tsuji, K. and Mitsusada, N. 2003. Kankou budou en raiensha no shouhi koudou to kankou nouen no kadai: Wakayama ken "Arita kyohou mura" wo jirei ni (Tourist behavior and problem in the pick-your-own grape farm). Agricultural Management Review 215: 18-21. (J)

Tsujihara, Y. 2007. Kankou nouen (Pick-your-own farm). In Kankou gaku daijiten (Encyclopedia of tourism), ed. M. Kagawa, 108 pp., Tokyo: Kirakusha. (J)
Ueda, S., Hoshino, S. and Sato, T. 2002. Establishment of producers' network in regional cooperation and its effects: The case study of the sera tablelands comprehensive industries' network, Hiroshima Prefecture. Journal of Rural Planning 21(2): 153162. (J)

Umeda, K. 2008. Regional learning system and technical development in dairy farming region. Geographical Sciences 63: 131-142.

Wampler, R. L. and Motes, J. E. 1984. Pick-your-own farming-cash crops for small acreages. Norman: University of Oklahoma Press.

Wilson, S., Fesenmaier, D. R., Fesenmaier, J. and Van Es, J. C. 2001. Factors for success in Rural Tourism Development. Journal of Travel Research 40 (2): 132-138.

Yamamura, J. and Ura, T. 1982. The trend of tourist farms in urbanized region along the River Tama, Kawasaki city, Kanagawa Prefecture. The New Geography 30(2): 1-18. (JE)

Yamashita, M. 1987. Yamagata-ken ni okeru kajitsu kandume no seisan keitai: sakuranbo kandume wo chushin to shite (A production system of fruit canned food in Yamagata Prefecture). Chiiki Chosa Houkoku (University of Tsukuba) 9: 81-90. (J)

Yamazaki, M. 1997. Agri-tourism business and farm tourism. In Kankou gaku jiten (Dictionary of tourism), ed. M. Haseyama, 84-85. Tokyo: Dobunkan. (J)

Yokoyama, H. 1998. Some problems related to the development of green tourism in Japan: Comparative study with Europe. Economic and Business Review (Kyushu Sangyo University) 39(1): 81-98. (J)

( J ): written in Japanese

(JE): written in Japanese with English abstract 